equally well. And the two years have something else in common: political investment in science sits at a crossroads.

On 9 July, a group of scientists set up to advise the United Nations secretary-general Ban Ki-moon startled many researchers with a bold assertion: nations should invest up to $3.5 \%$ of their gross domestic product (GDP) in science.

Cue snorts of derision. Although a tiny group of nations invests around this much - Sweden and Israel among them - most fall well below this threshold. According to the latest figures from the Organisation for Economic Co-operation and Development, the United States invests $2.7 \%$, and China $2 \%$. The European Union average comes in at just under $2 \%$.

Even the UN science advisory board admits that a target of $1 \%$ is perceived as high by many governments. It does, however, say that $3.5 \%$ of GDP is necessary to put the world on a sustainable development course. If this target seems rather arbitrary, it is because it probably is. But this crude measure of support for science can still be a useful metric.

Take the case of the United Kingdom. Combined private and public spending on UK science is around 1.6\% of GDP. Earlier this year, the heads of various learned societies called for politicians to increase this figure to $3 \%$, but the plea raised little more than eyebrows.

An ambition to boost government spending on science might have received a more welcome response in 2009 - but since then austerity has dominated in the United Kingdom. The ConservativeLiberal Democrat coalition government that came to power in 2010 did fulfil its promise to protect the core UK science budget from cuts, but inflation has whittled away the amount that is available for research.

Following last week's UK budget statement, there are signs that austerity measures are being relaxed - for some at least. In the first fiscal plan produced by a majority Conservative government for nearly two decades, Chancellor of the Exchequer George Osborne announced some cuts - to welfare benefits and national broadcaster the $\mathrm{BBC}$, for example - but he also unveiled significant belt-loosening measures, including tax cuts for the middle classes.

Exactly what this means for science is not yet clear. The Conservatives say that they will cut about $£ 17$ billion (US $\$ 26$ billion) from government departments. Some of these axe blows may fall on research spending.

But the party has been vocal in its support for some scientific pro-
"If there is money to cut

taxes, there should be money

to support

the work that

can drive economies." jects. They have championed the (nebulous) term 'innovation' as key to improve the Britain's woeful workplace productivity. And cash has flowed, up to a point, to huge projects such as the Francis Crick Institute for biomedical research in London and the National Graphene Institute in Manchester.

Still, of Britain's 1.6\% of GDP spent on science, the public spend makes up just $0.44 \%$. Compare that with Germany, where the government contributes $0.85 \%$ of GDP out of an overall spend on science of $2.9 \%$ of GDP. And the US government spends $0.76 \%$ of GDP out of an overall investment in science of $2.7 \%$ of GDP.

If Osborne is serious about science, now is the time to prove it. At a parliamentary gathering last month, at which politicians rubbed shoulders with researchers, the subject of science funding was on the lips of many. A reference to the percentage of GDP spent on science has become de rigueur in such conversations, often with an addendum that the United Kingdom 'punches above its weight' in achieving what it does with its limited means. This attitude has almost become part of the political identity of UK science: 'we do so well with so little - why not give us more money and let us show you what we can really do'.

It has a point - if there is money to cut taxes, there should be money to support the work that can drive economies.

There are, of course, many claims on public financing, and scientists must be prepared to fight for their share alongside hospital administrators, road builders and arts funders. But if the UK government wishes to continue to wear the mantle of a science supporter, pushing towards $3.5 \%$ would be a step in the right direction.

\section{An education}

\section{A special issue looks at how science is taught - and why a change in methods is essential.}

$\mathrm{O}$ ne of the subjects that people love to argue about, following closely behind the 'correct' way to raise children, is the best way to teach them. For many, personal experience and centuries of tradition make the answer self-evident: teachers and textbooks should lay out the content to be learned, students should study and drill until they have mastered that content, and tests should be given at strategic intervals to discover how well the students have done.

And yet, decades of research into the science of learning has shown that none of these techniques is particularly effective. In universitylevel science courses, for example, students can indeed get good marks by passively listening to their professor's lectures and then cramming for the exams. But the resulting knowledge tends to fade very quickly, and may do nothing to displace misconceptions that students brought with them.

Consider the common (and wrong) idea that Earth is cold in the winter because it is further from the Sun. The standard, lecture-based approach amounts to hoping that this idea can be displaced simply

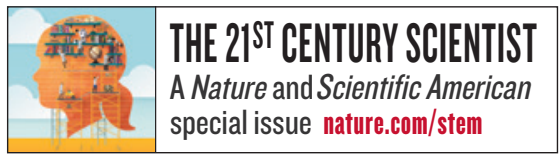

by getting students to memorize the correct answer, which is that seasons result from the tilt of Earth's axis of rotation. Yet hundreds of empirical studies have shown that students will understand and retain such facts much better when they actively grapple with challenges to their ideas - say, by asking them to explain why the northern and southern hemispheres experience opposing seasons at the same time. Even if they initially come up with a wrong answer, to get there they will have had to think through what factors are important. So when they finally do hear the correct explanation, they have already built a mental scaffold that will give the answer meaning.

In this issue, prepared in collaboration with Scientific American, Nature is taking a close look at the many ways in which educators around the world are trying to implement such 'active learning' methods (see page 271). The potential pay-off is large - whether it is measured by the increased number of promising students who finish their degrees in science, technology, engineering and mathematics (STEM) disciplines instead of being driven out by the sheer boredom of rote memorization, or by the non-STEM students who get first-hand experience in enquiry, experimentation and reasoning on the basis of evidence.

Implementing such changes will not be easy - and many academics may question whether they are even necessary. Lecture-based education has been successful for hundreds of years, after all, and - almost by definition - today's university instructors are the people who thrived on it.

But change is essential. The standard system also threw away far
D NATURE.COM To comment online, click on Editorials at: go.nature.com/xhunqv too many students who did not thrive. In an era when more of us now work with our heads, rather than our hands, the world can no longer afford to support poor learning systems that allow too few people to achieve their goals. 